\title{
Ultrasonic Testing of Butt Weld Joint by TOFD Technique
}

Michal Boháčik ${ }^{1}$, Miloš Mičian ${ }^{1}$, Radoslav Koňár ${ }^{1}$, Ivo Hlavatý

${ }^{1}$ University of Žilina, Faculty of Mechanical Engineering, Univerzitná 8215/1, 01026 Žilina. Slovak Republic. E-mail: michal.bohacik@fstroj.uniza.sk, milos.mician@fstroj.uniza.sk, radoslav.konar@fstroj.uniza.sk

${ }^{2}$ VŠB - Technical University of Ostrava, Faculty of Mechanical Engineering, 17. listopadu 2172/15

70833 Ostrava - Poruba, Česká republika. E-mail: ivo.hlavaty@vsb.cz

The aim of the article was to check the internal defects in the butt welded joints by non-destructive TOFD (Time of Flight Diffraction) technique. Subsequently, the macrostructure from the defect indication site was evaluated and assigned to the TOFD ultrasound indication. Basic knowledge of ultrasonic TOFD testing are described in the theoretical part of a submitted paper. Ultrasound technique TOFD is non-destructive method that can detect internal defects inside test material without damaging it. It is a reliable method for detecting mainly flat internal defects such as incomplete root penetration, lack of fusion, etc. Ultrasonic test procedures and test results obtained in non-destructive testing of butt weld are shown in experimental part. Evaluation of the ultrasonic TOFD testing results, its advantages and disadvantages are described at the end of this article.

Keywords: Internal defects, Butt welded joints, TOFD, Non-destructive testing.

\section{Acknowledgement}

This work has been supported by Scientific Grant Agency of Ministry of Education of the Slovak republic, grant KEGA: 034ZU-4/2015.

\section{References}

[1] LANGENBERG, K., J., MARKLEIN, R., MAYER, K. (2012). Ultrasonic nondestructive testing of materials Theoretical foundations. p. 772. CRC Press, New York. ISBN 978-14-398-5588-1

[2] MORAVEC, J., NOVAKOVA, I., BRADAC, J., (2014) Effect of Age Hardening Conditions on Mechanical Properties of AW 6082 Alloy Welds. In: Manufacturing technology: journal for science, research and production, 2016, Vol. 16, No.1, pp. 192-198. J.E. Purkyne University, Usti nad Labem. ISSN 1213-2489.

[3] KREJCI, L., HLAVATY, I., ŠEVČÍKOVÁ, X. (2013) Transition Zones Study of the Heterogenous Welded Joints. Metal 2013. Brno: 2013, pp. 785-789, ISBN 978-80-87294-41-3.

[4] HLAVATÝ, I., KOZAK, J., KREJČI, L. (2016) Study of the Deposit Properties Contained Tungsten Carbides in the Iron Matrix. Metal 2016. Brno: 2016, pp. 1056-1060, ISBN 978-80-87294-67-3.

[5] KONAR, R., MICIAN, M. (2014). Non-destructive testing of welds in gas pipelines repairs with Phased Array ultrasonic technique. In: Manufacturing technology: journal for science, research and production, Vol. 14, No. 1, pp. 42-47. J.E. Purkyne University, Ústi nad Labem. ISSN 1213-2489.

[6] OLYMPUS (2013). The company Olympus NDT. Online: <http://www.olympus-ims.com/cs>.

[7] KOPEC, B. et al. (2008) Nondestructive Testing of Materials and Structures, p. 573, CERM, s.r.o.: Brno, 2008, ISBN 978-80-7204-591-4.

[8] BOHACIK, M. (2016). Comparison of the reliability of the identifications of internal defects butt welded joints by ultrasonic and x-ray checking: Diploma work. Zilina: University of Zilina in Zilina, 2016. 67s.

[9] FATURÍK, M. - MIČIAN, M. - KOŇÁR, R. (2016) Ultrasonic identification of weld defects made by electrofusion welding on plastic pipelines. In: Manufacturing technology : journal for science, research and production. ISSN 1213-2489. - Vol. 16, no. 1 (2016), s. 76-81.

[10] VRZGULA, P. - FATURÍK, M. - MIČIAN. (2014) New inspection technologies for identification of failure in the materials and welded joints for area of gas. In: Manufacturing technology : journal for science, research and production. - ISSN 1213-2489. - Vol. 14, no. 3 (2014), s. 487-492.

[11] KOŇÁR, R. - MIČIAN, M. - HLAVATÝ, I. (2014) Defect detection in pipelines during operation using Magnetic Flux Leakage and Phased Array ultrasonic method In: Manufacturing technology: journal for science, research and production. - ISSN 1213-2489. - Vol. 14, no. 3 (2014), s. 337-341.

[12] ZRAK, A. - MEŠKO, J. - MORAVEC, J. - NIGROVIČ, R. - KADÁŠ, D.(2016) Contactless thermal bending of steel sheets. In: Manufacturing technology: journal for science, research and production. - ISSN 1213-2489. Vol. 16, no. 1 (2016), s. 309-313. 
[13] NIGROVIČ, R. - MEŠKO, J. (2016) Laser cutting of non-metallic material. In: Manufacturing technology: journal for science, research and production. - ISSN 1213-2489. - Vol. 16, no. 2 (2016), s. 402-406

[14] SEJČ, P. - BIELAK, R. - ŠVEC, P. - ROŠKO, M. (2006) Computer simulation of heat affected zone during MIG brazing of zinc-coated steel sheets. In Kovové materiály. Metallic materials. Roč. 44, č. 4 (2006), s.225-234. ISSN $0023-432 X$.

\section{Paper number: M2017164}

Copyright $(\mathcal{C}$ 2017. Published by Manufacturing Technology. All rights reserved. 